\title{
Epiphrenic pulsion diverticulum: an uncommon cause of dysphagia and heartburn
}

\author{
Choon-Seng Qua, ${ }^{1}$ Kannan Saravannan, ${ }^{2}$ Khean-Lee Goh (i) ${ }^{3}$
}

${ }^{1}$ Gastroenterology, Mahkota Medical Centre, Melaka, Malaysia

${ }^{2}$ Radiology, Mahkota Medical Centre, Melaka, Malaysia ${ }^{3}$ Medicine, University of Malaya Faculty of Medicine, Kuala Lumpur, Malaysia

\section{Correspondence to}

Professor Khean-Lee Goh: klgoh56@gmail.com

Accepted 25 March 2021

\section{Check for updates}

(C) BMJ Publishing Group Limited 2021. No commercial re-use. See rights and permissions. Published by BMJ.

To cite: Qua C-S,
Saravannan K, Goh K-L. BMJ
Case Rep 2021;14:e242920.
doi:10.1136/bcr-2021-
242920

\section{DESCRIPTION}

A 52-year-old Malay man presented with a history of recurrent heartburn and intermittent dysphagia for 6 months. There was no history of vomiting or food regurgitation or any alarming symptom. He had previously sought treatment from several doctors with a presumptive diagnosis of gastro-oesophageal reflux disease and was given treatment with proton pump inhibitors (PPIs). His symptoms were typically worse after meals and on lying down at night. He is a nonsmoker and non-drinker with a body mass index of $25 \mathrm{~kg} / \mathrm{m}^{2}$. His physical examination was unremarkable.

He underwent a gastroscopy, which showed thickened folds in the lower oesophagus with marked muscular contractions. There was some luminal narrowing, but no oesophagitis nor any other mucosal abnormality was detected. His proximal oesophagus was not dilated and there was no impacted food detected.

He was given a course of PPIs and a prokinetic drug (domperidone) for 1 week. He reported only minimal improvement in his symptoms. A barium swallow was then performed. This showed an initial smooth flow of contrast from hypopharynx down to the distal oesophagus with the distal half of oesophagus gradually dilating on filling with contrast. However, contrast hold-up was seen in the distal oesophagus (figure 1A), followed by gradual contrast filling of an outpouching on the left side of distal oesophagus just above the hemidiaphragm (figure 1B), in addition to abnormal peristaltic patterns detected at the distal oesophagus. The contrast filled outpouching and distal oesophagus gradually emptied into the stomach (figure 1C).

On an oblique view of the barium studies, the size of the diverticulum was measured to be 3.92 $\mathrm{cm} \times 4.82 \mathrm{~cm}$ (figure 2).

These findings finally led to the diagnosis of epiphrenic pulsion diverticulum (EPD) with possible underlying oesophageal dysmotility. The patient was advised to undergo a formal manometry to detect any underlying oesophageal motility disorder, which we strongly suspected, as he likely requires surgery in view of persistent symptoms and the large size of the diverticulum. However, the patient chose conservative management for now. $\mathrm{He}$ was given dietary advice, including avoiding large meals, chewing slowly, frequent intake of water during food and avoiding postprandial recumbency. He was prescribed PPIs for symptomatic control of his reflux symptoms.

EPD is rare type of diverticulum involving the lower oesophagus and is thought to be due to increased intraluminal pressure in the oesophagus. It is sometimes called a 'false diverticulum' as there

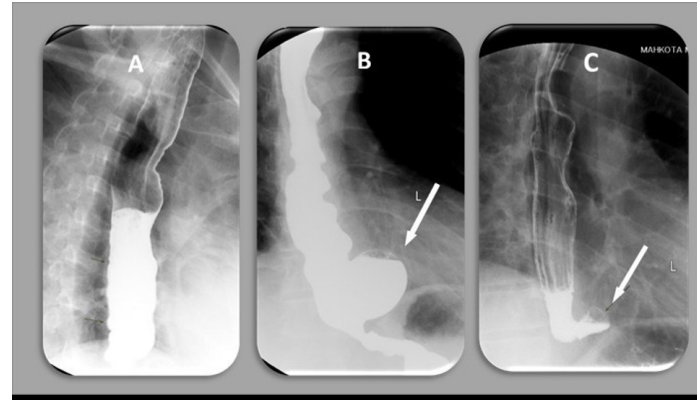

Figure 1 Barium swallow showing (A) contrast holdup at the lower oesophagus, (B) gradual filling of the diverticulum and (C) gradual emptying of contrast into the stomach.

is focal herniation of the mucosa and submucosa through the muscularis propria in the absence of muscularis layers in the wall of the diverticulum. It is an uncommon condition, which can occur anywhere in the oesophagus, but often occurs in the lower oesophagus where the point of anatomical weakness in the oesophageal wall is where nerves and blood vessels enter to supply the lower oesophagus. It is believed to be associated with underlying motility disorders. The resultant symptoms experienced by the patient would depend on the site and the size of the diverticulum. Commonly reported symptoms include dysphagia, food regurgitation, vomiting, retrosternal discomfort, heartburn, aspiration pneumonia and sometimes food impaction. Many of these symptoms mimic other common gastrointestinal diseases, making diagnosis

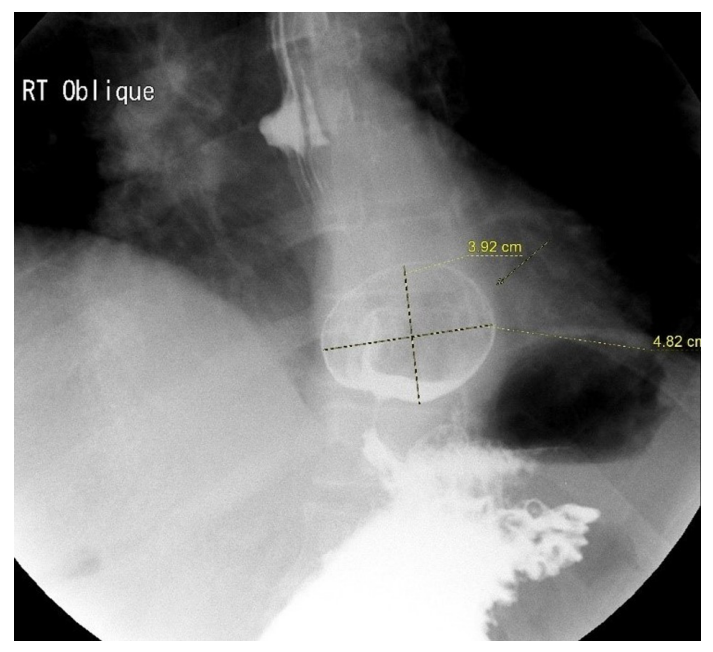

Figure 2 Barium swallow showing the large diverticulum. 
challenging to primary care physicians. A contrast study remains the investigation of choice for this condition. ${ }^{1}$ The estimated incidence of EPD is about 1:500 000/year. ${ }^{2}$ It is most commonly associated with achalasia. ${ }^{3-6}$ It is also associated with a small risk of malignancy, especially in elderly men with longstanding symptoms. $^{7}$

For symptomatic patients with large diverticula, surgery remains the treatment of choice. This usually involves diverticulectomy or diverticulopexy with or without myotomy, which can be performed via an open or minimally invasive approach. For symptomatic patients who are unfit for or refuse surgery, endoscopic pneumatic dilation and botulinum toxin injection remain viable alternatives. ${ }^{2} 8$

In a comprehensive review by Sonbare, ${ }^{9}$ surgical treatment for this type of diverticulum is associated with significant morbidities, including postoperative leaks. ${ }^{10} 11$ For small EPD with minimal symptoms, patients may be managed conservatively.

\section{Patient's perspective}

I am surprised to learn that the cause of my symptoms is something rare and different from what I had been told before. However, I do feel relieved that at least it is not cancer of some sort, which I had initially suspected. I will think about going for surgery later as advised by my doctor.

\section{Learning points}

- Epiphrenic pulsion diverticulum is a rare form of oesophageal diverticulum due to increased intraluminal pressure.

- It is an uncommon cause of dysphagia and heartburn.

- Gastroscopy, barium and manometry studies are essential to help guide clinicians decide the best treatment for each patient.
Contributors C-SQ wrote the manuscript and was primarily responsible for the patient's care. K-LG contributed to the writing of the manuscript. KS performed the radiological investigations.

Funding The authors have not declared a specific grant for this research from any funding agency in the public, commercial or not-for-profit sectors.

Competing interests None declared.

Patient consent for publication Obtained.

Provenance and peer review Not commissioned; externally peer-reviewed.

\section{ORCID iD}

Khean-Lee Goh http://orcid.org/0000-0002-9965-1561

\section{REFERENCES}

1 Khan N, Ismail F, Van de Werke IEA. Oesophageal pouches and diverticula: a pictorial review. S Afr J Surg 2012;50:71-5.

2 Zaninotto G, Portale G, Costantini M, et al. Therapeutic strategies for epiphrenic diverticula: systematic review. World J Surg 2011;35:1447-53.

3 Soares R, Herbella FA, Prachand VN, et al. Epiphrenic diverticulum of the esophagus. from pathophysiology to treatment. J Gastrointest Surg 2010;14:2009-15.

4 Vicentine FPP, Herbella FAM, Silva LC, et al. High resolution manometry findings in patients with esophageal epiphrenic diverticula. Am Surg 2011;77:1661-4.

5 D'Journo XB, Ferraro P, Martin J, et al. Lower oesophageal sphincter dysfunction is part of the functional abnormality in epiphrenic diverticulum. Br J Surg 2009:96:892-900

6 Melman L, Quinlan J, Robertson B, et al. Esophageal manometric characteristics and outcomes for laparoscopic esophageal diverticulectomy, myotomy, and partial fundoplication for epiphrenic diverticula. Surg Endosc 2009;23:1337-41.

7 Herbella FAM, Patti MG. Modern pathophysiology and treatment of esophageal diverticula. Langenbecks Arch Surg 2012;397:29-35.

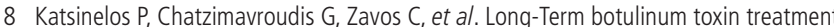
for dysphagia due to large epiphrenic diverticulum in elderly patients: a report of two cases. Dysphagia 2009;24:109-13.

9 Sonbare DJ. Pulsion diverticulum of the oesophagus: more than just an out pouch. Indian J Surg 2015;77:44-8.

10 Benacci JC, Deschamps C, Trastek VF, et al. Epiphrenic diverticulum: results of surgical treatment. Ann Thorac Surg 1993;55:1109-14.

11 Fernando HC, Luketich JD, Samphire J, et al. Minimally invasive operation for esophageal diverticula. Ann Thorac Surg 2005;80:2076-80.

Copyright 2021 BMJ Publishing Group. All rights reserved. For permission to reuse any of this content visit

https://www.bmj.com/company/products-services/rights-and-licensing/permissions/

BMJ Case Report Fellows may re-use this article for personal use and teaching without any further permission.

Become a Fellow of BMJ Case Reports today and you can:

- Submit as many cases as you like

- Enjoy fast sympathetic peer review and rapid publication of accepted articles

- Access all the published articles

Re-use any of the published material for personal use and teaching without further permission

Customer Service

If you have any further queries about your subscription, please contact our customer services team on +44 (0) 2071111105 or via email at support@bmj.com.

Visit casereports.bmj.com for more articles like this and to become a Fellow 